\title{
KORUPSI DAN PERLUNYA TEOLOGI BARU DI SEKTOR PUBLIK
}

Oleb: Saefur Rocbmat*

\section{Abstract}

New theology of public sphere pretends to counter secularism in modern era by breaking the separation wall of public and private affairs. It agrees with the secularization of public affairs which separates the management of public affairs of the state with that of the private affairs of religion, but both should develop dialogue to build bumanistic civilization. Islam should revitalize its legal Islamic law (figh) in order not to emphasize its orientation to Pillars of Islam (Rukun Islam/community sector, but try to make balance with Pillars of Belief(Rukun Iman/private sector). It will result in Pillars of Public Sector as a kind of intermingle between Rukun Islam and Rukun Iman.

استهلفت النظرية اللاهوتية الجلديلة مضادة لنظرية العلمانية الحديثة اليّ تعني كل ما هو واقعي ومللي وغير ديني، وذلك تميزا له عن الأشياء الروحانية. حاول الباحث جهده لبناء الحوار بين الثقافة علمانية اللذي يتمسك بقيم أساسية نفعية وعقلانية والذّي يقبل التغيير والتجديل ويشتعها وين الثُقافات الروحانية التي هَتم بالمقدسات والقوى الحلارقة للطبيعة أو بالقيم المتصلة بالتقاليد والترعة المحافظة مستهلفا لبناء الحضارة الإنسانوية. وتأسيسا على هذا فإن البحتمع المُسلم عحتاجون إلى إعادة صياغة تعاليم الإسلامية الملا ئمة بالأحوال والظروف الحلديثة. Kata kunci: sekulerisme, teologi, dan sektor publik

* Saefur Rochmat, MIR. adalah dosen Jurusan Sejarah, FIS Universitas Negeri Yogyakarta. Menyelesaikan master Hubungan Internasional di Ritsumeikan University,Kyoto-Jepang. Tulisannya yang sudah dimuat di Millah adalah "Studi Islam di Indonesia Era Millenium Ketiga" tahun 2002. 


\section{A. Pendabuluan}

Indonesia dapat dikatakan sebagai negara Islam, dalam arti mayoritas penduduknya beragama Islam. Tetapi ironisnya, Indonesia merupakan salah satu negara terkorup di dunia. Hal ini menunjukkan kita sedang menderita krisis akut di era modern sekarang ini. Suka atau tidak suka dengan sebutan periodisasi modern ini, kita sedang hidup di alam modern, bila dilihat feature dan karakteristik kehidupan yang sedang kita jalani.

Kita dapat segera keluar dari krisis akut ini bila kita mau belajar dari pengalaman Barat, yang sudah lebih dulu memasuki era modern, lalu mencarikan solusi yang tepat dari keadaan ini. A pa yang sedang terjadi di Indonesia sekarang ini persis seperti yang terjadi di Barat dulu. Bila kita tidak mau belajar dari kesalahan Barat maka hasilnya pun akan sama saja, kita menjadi negara yang "atheis" seperti Barat.

Mungkin tidak dalam artian simbol, tetapi pada substansinya kita sudah jumbuh dengan sikap atheis. Secara simbolik memang umat Islam sulit menjadi atheis, karena beberapa alasan: Pertama, kita mempunyai kitab suci al-Qur'an yang dijamin keasliannya oleh Allah SWT. Kedua, tidak seperti Kristen yang menekankan aspek kepercayaan (beliefs), agama Islam menekankan juga aspek ibadah atau dikenal dengan aspek hukum (laws), dalam arti ritual-ritual agama yang tidak memberi tempat pada atheisme simbolik.

Al-Qur'an tidak perlu dirisaukan keasliannya, tetapi kita tentu terus ditantang agar memahami al-Qur'an secara benar dan komprehensif. Bisakah al-Qur'an digunakan untuk menjelaskan proses kehidupan yang sedang berlangsung sekarang? Dengan kata lain, bisakah al-Qur'an menjelaskan gejala kehidupan modern sekarang ini?

Lalu apakah hukum-hukum agama yang diturunkan dari al-Qur'an tidak hanya bersifat ritual belaka, namun sungguh-sungguh mencerminkan kehendak Allah yang sebenarnya? Mengingat banyak konsep dalam al-Qur'an yang perlu dijabarkan lebih lanjut dalam operasionalisasinya. Contohnya, korupsi pada zaman dahulu dengan korupsi pada masa sekarang ini tentu berbeda, karena struktur masyarakatnya sudah berbeda. Mengingat perkembangan suatu masyarakat tidak sama maka kita perlu mengakomodasi berbagai macam paradigma pemikiran, sehingga suatu masyarakat bebas memilih paradigma yang sesuai dengan situasi dan kondisi maupun karakteristik daerahnya.

Salah satu paradigma yang ingin ditawarkan melalui artikel ini adalah perlunya disusun suatu teologi baru, yaitu suatu teologi yang memanfaatkan kemajuan ilmu "keduniawiaan" baik dalam filsafat maupun iptek modern. Hal ini perlu dilakukan karena teologi ini berpretensi menangkal sekulerisme di sektor publik. 


\section{B. Spiritualisme Individual di Barat}

"Atheis"1 disini bukan berarti orang Barat tidak percaya kepada kekuatan adikodrati atau Tuhan, tetapi mereka tidak percaya lagi kepada Injil yang dipandangnya tidak dapat menawarkan solusi yang tepat atas krisis yang melanda kehidupan modern. Tidak percaya kepada Injil berarti tidak percaya kepada bimbingan Tuhan yang disampaikan melalui Nabi-Nya Isa.

"Atheis" perlu diberi tanda petik karena bukan berarti orang Barat tidak percaya lagi kepada Tuhan. Dalam suatu survey di sepuluh negara mengenai kepercayaan agama di era modern sekarang ini, yang dilakukan oleh lembaga research ICM dan dipublishkan di radio BBC menunjukkan bahwa meskipun kita sedang mengalami proses modernisasi yang intense, yaitu menilai tinggi aspek materi (suatu kecenderungan sekularisme), tetapi sebagian besar orang $92 \%$ masih percaya kepada kekuatan adikodrati dan di Amerika sendiri, suatu negara yang modern dan telah mengalami proses modernisasi begitu lama, $91 \%$ orang masih percaya kalau kehidupan akan lebih damai kalau percaya pada Tuhan. ${ }^{2}$

Fenomena tidak mau mengikuti agama-agama formal (khususnya Yahudi dan Kristen) tetapi masih percaya kepada kekuatan adikodrati Tuhan dapat ditemukan pada diri pendiri negara Amerika Thomas Jefferson (1743-1826). Memang dia dituduh atheis, namun sebenarnya dia menganut "deisme". Padahal deisme bukanlah ateisme, justru sebaliknya. Meskipun barangkali tidak sampai kepada taraf "theisme", yaitu paham Ketuhanan menurut agama, "deisme" adalah pandangan yang didasarkan kepada pengakuan akan adanya Tuhan. Hanya saja, berbeda dengan "theisme", Tuhan menurut "deisme" lebih mirip dengan hukum alam yang tidak bersifat pribadi (impersonal). Berbeda dengan kaum theis dalam agama-agama, kaum deis tidak mempercayai adanya Tuhan "aktif" yang mencampuri urusan manusia. ${ }^{3}$

Sebagai seorang deis, dia memasukkan ide-ide Ketuhanan dalam Deklarasi Kemerdekaan Amerika, namun Tuhan tidak dalam artian agama Kristen, melainkan "Tuhan" yang lebih "alami". Karena itu, ia menggunakan ungkapanungkapan Lawes of Nature dan Nature's God, selain istilah divine Providence. Bahkan di dalam mata uang dollar ditulis In God We Trust. ${ }^{4}$

${ }^{1}$ Atheis secara harfiah berarti orang yang tidak percaya pada Tuhan atau paham Ketuhanan menurut agama, namun disini dipergunakan secara spesifik. Lihat Nurcholish Madjid (1995), Islam Agama Peradaban: Membangun Makna dan Relevansi Doktrin Islam dalam Sejarab, Jakarta: Paramadina, p.150.

${ }^{2}$ BBC News (2004), “UK among most secular nations", dalam http://news.bbc.co.uk/1/hi/ programmes/wtwtgod/3518375.stm, pp.1-3<Diakses 2005/06/20>.

${ }^{3}$ Nurcholish Madjid, op. cit, pp.150-151. 
Bila kita amati lebih dalam lagi maka baik atheisme maupun deisme merupakan gejala pemberontakan kepada agama-agama mapan, dan masingmasing menyangkut masalah yang sangat penting untuk dikaji. Deisme perlu mendapatkan perhatian lebih karena ia mengandung beberapa hal yang cukup positif. Pertama, seperti dicerminkan dalam pandangan Jefferson, kaum deis sangat percaya kepada ukuran-ukuran budi pekerti yang luhur. Kedua, mereka percaya kepada adanya agama alami (istilah al-Qur'an, fithri), yang merupakan bentuk asli dan primordial agama umat manusia, namun kemudian mengalami penyimpangan-penyimpangan sehingga Tuhan perlu mengangkat para Nabi untuk meluruskannya. Berkaitan dengan Kristen dan hubungannya dengan sejarah universal agama-agama dikatakan:

The role of Cbristianity in the universal bistory of religion became problematic. For many religious deists the teachings of Christ were not essentially novel but were in reality as old as creation, a republication of primitive monotheism. Religious leaders bad arisen among many people such as Socrates, Buddba, Mobammed and their mission had been to effect the restoration of the simple religious faith of early man.s

Hasil survey ICM tersebut merupakan sesuatu yang wajar bila kita sadar kalau manusia itu mempunyai perjanjian primordial dengan Tuhan, yang terjadi sebelum kita lahir ke bumi. Perjanjian atas inisiatif Tuhan ini merupakan bentuk bimbingan Tuhan pada manusia yang nisbi (tidak mutlak) karena Kemutlakan hanya ada pada Kemahaesaan. Perjanjian primordial ini adalah suatu kesaksian dan pengakuan oleh manusia bahwa Allah, Tuhan Yang Maha Esa, adalah Tuhan $(R a b b)$, seperti yang termuat dalam Q.S. al-A'râf: 172. Kesaksian dan pengakuan ini mengandung makna kesediaan untuk tunduk, patuh, taat dan pasrah atau ber-islâm kepada-Nya, yang sikap-sikap itu harus dipertanggungjawabkan di hari kiamat, baik itu berhasil atau gagal. ${ }^{6}$

Berdasarkan adanya perjanjian primordial itu, maka tidak ada sifat kemanusiaan yang lebih asasi daripada naluri untuk mengabdi, yaitu hasrat alami untuk menyembah. Jadi lokus rekaman perjanjian primordial itu ada dalam alam rohani manusia, jauh lebih dalam daripada alam bawah sadar psikologisnya. Memang perjanjian ini seringkali terkikis oleh alam bawah sadarnya yang terus mempengaruh pengalaman manusia baik dalam keadaan sedih maupun bahagia. Bila manusia berhasil mempertanggungjawabkan perjanjian primordial ini secara berhasil maka dia akan mendapatkan kedudukan yang tinggi di sisi Allah.

${ }^{4}$ Ibid, pp.150-151.

${ }^{5} \mathrm{Ibid}, \mathrm{p} .152$.

${ }^{6}$ Nurcholis Madjid (1998), "Dialog Agama-agama dalam Perspektif Universalisme alIslam”, dalam Komaruddin Hidayat dan Ahmad Gaus AF eds. Passing Over: Melintas Batas Agama, 
Memang hasil survey ICM itu sungguh mencengangkan karena Barat masih percaya kepada Tuhan, walaupun mereka telah mengalami proses modernisasi atau sekularisasi sejak masa Renaissance pada abad ke-15. Memang mereka tidak lagi menjalankan ritual agama Kristen karena mereka tidak lagi percaya kepada Injil, yang telah gagal menawarkan solusi bagi kehidupan modern, bahkan menjadi penyebab munculnya kekerasan-kekerasan antar sesama umat beragama yang berbeda pandangan. Lalu mereka berpaling kepada warisan peradaban Yunani dan Romawi kuno dalam mengatasi krisis yang sedang terjadi, dengan cara mengerahkan segala kemampuan rasionalnya, karena mereka percaya kalau Tuhan menganugerahkan akal memang untuk mencari kebenaran.

Mereka lupa bahwa kemampuan akal manusia pun bersifat nisbi, sehingga dari peradaban ini telah pecah dua kali Perang Dunia, dua kali Perang Teluk, dan banyak revolusi yang menginjak-injak rasa kemanusiaan. Semuanya berangkat dari krisis yang melanda sektor publik di Barat.

\section{Sekulerisme Sektor Publik di Barat}

Konsekuensi logis dari tidak mempercayai lagi Injil, Barat tidak lagi melakukan ritual agama, walaupun warisan sisa-sisa peradaban Kristen masih dapat dijumpai sekarang ini. Memang dalam lubuk hatinya mereka masih mengakui eksistensi Tuhan, dan akan menjadi alternatif terakhir bila mereka tidak dapat lagi mengatasi krisis yang menimpanya. Ada tiga hal yang bisa ditarik dari uraian ini, yaitu: (1) secara individu, mereka masih mempercayai Tuhan, tetapi (2) secara publik, mereka tidak mengembangkan peradaban yang sesuai dengan misi agama, atau yang disebut dengan sekularisme dalam ruang publik dan (3) dalam realita, antara aspek private dan aspek public tidak dapat dipisahkan secara diametral. ${ }^{7}$

Sementara itu, deisme yang dikembangkan Thomas Jefferson dkk. pada masa awal kemerdekaan tidak cukup untuk membendung laju sekulerisme yang sedang melanda Barat modern. Ada beberapa hal yang menjadi penyebab dari kegagalan ini. Pertama, deisme belum berhasil mengembangkan pemikiran sintesis dari pendekatan teologi dengan iptek dan filsafat. Kedua, karena perbedaan teologi dalam Yahudi maupun Kristen sangat tajam maka deisme cenderung mengikuti jalan peradaban Yunani-Romawi kuno yang lebih terpengaruh paham sekulerisme. Peradaban ini selalu mempertentangkan manusia dengan Tuhan (dewa-dewa) yang menguasai alam semesta ini dan kekuatan para dewa itu diperoleh berkat kebodohan manusia yang belum berhasil mengembangkan

Jakarta: Gramedia, pp.10-11.

${ }^{7}$ Saefur Rochmat (2005), "Kebangkitan Agama di Era Modern?" dalam Inovasi, Tahun 7, 
iptek. Ketiga, deisme cenderung mengembangkan pemikiran yang bersifat naturalisme (banyak mengandung unsur sekulerisme), sebagai upaya untuk menggugat paham negara theokrasi Inggris, yang meyakini Raja sebagai pemilik bumi yang sah karena mendapatkan mandat dari Tuhan dan mencari legitimasi bagi negara yang akan didirikan oleh Jefferson dkk.

Sekularisme dalam ruang publik terjadi karena kepercayaan individual pada Tuhan tidak dimanifestasikan dan dimplementasikan dalam hal-hal yang berkaitan dengan masalah publik. Bukankah modernisasi ditandai dengan gerakan sekularisasi, yang memisahkan pengaturan urusan private dengan urusan publik. Pemisahan ini dimaksudkan untuk mencegah terjadinya korupsi agama, yaitu agama digunakan untuk tujuan-tujuan politik atau yang dikenal dengan politisasi agama. Dengan demikian, hal-hal yang menyangkut kepentingan publik, terutama yang berkaitan dengan masalah pengaturan negara dan hubungan antar negara, diatur lepas sama sekali dari bimbingan agama. Dengan demikian, sekularisasi dapat digunakan untuk tujuan yang mulia, mencegah politisasi agama dan memang kebenaran agama bersifat obyektif, yaitu suatu kebenaran yang ada berkat eksistensinya dan bukan karena dukungan-dukungan kekuatan politik. Kekuatan politik tidak demi agama an sich tetapi demi kepentingan kelompok tertentu.

Sekulerisme terjadi karena para tokoh agama dengan para ilmuwan gagal mencari kompromi. Masing-masing mengembangkan ilmu yang saling bertentangan dan tidak berhasil melakukan sintesa terhadap ilmu-ilmu tersebut. Agamawan mengembangkan teologi, yaitu ilmu yang memperlajari tentang Ketuhanan; sedangkan para ilmuwan mengembangkan ilmu pengetahuan modern dan filsafat. Memang kemudian terjadi sintesa dari keduanya, atas inisiatif pihak ilmuwan yang mencoba mengkaitkan masalah ilmu-ilmu modern dan filsafat dengan persoalan teologi, bahkan mereka berani memberikan ceramah masalah agama, suatu yang menjadi monopoli pihak agamawan. Peristiwa yang menandai terjadinya sintesa teologi dengan iptek dan filsafat dikenal sebagai lahirnya teologi baru. Teologi baru inilah yang melatarbelakangi lahirnya agama Kristen Protestan; dan gerakannya mendapat dukungan dari para politikus dan negarawan yang ingin mendirikan negara nasional.

Berkembangnya Kristen Protestan dalam negara nasional menunjukkan bahwa para tokoh agama Protestan, yang sedang mengembangkan suatu teologi baru, bekerjasama dengan mereka yang terjun dalam sektor publik. Kedua belah pihak memang memiliki perhatian yang sama, yaitu ingin mewujudkan suatu pemerintahan yang demokratis; dengan konsekuensi melawan tokoh agama yang mendukung sistem pemerintahan theokrasi. Antara keduanya ada kerjasama 
dalam menegakkan demokrasi, terutama melalui mekanisme check and balance, dimana negara tidak mau melakukan sentralisasi dalam hal yang berkaitan dengan sektor private maupun dalam hal berkaitan dengan penyelenggaraan kesejahteraan rakyat. Dalam hal ini, sektor private menjalankan peran sebagai unsur civil society, yang bertugas melakukan kontrol terhadap jalannya pemerintahan (sektor publik).

Hal tersebut dapat diamati dalam praktek pemerintahan di Amerika Serikat, dimana negara menyalurkan dana bagi kesejahteraan sosial kepada unsur-unsur civil society. Umumnya ada tiga tipe penyaluran dana pemerintah. Pertama, pemerintah membeli kontrak servis dari NGO-NGO (Non-Government Organizations). Kedua, pemerintah memberi bantuan langsung kepada NGONGO, seperti dalam bentuk grant, sumbangan, dan kredit lunak. Ketiga, pemerintah memberi bantuan kepada individu. Tidak mengherankan bila jumlah pegawai di NGO-NGO melebihi jumlah pegawai di seluruh negara bagian dan pemerintah federal sekaligus; dan besarnya budget juga melebihi budget di sektor publik. $^{8}$

Usaha para ilmuwan menggabungkan teologi dengan ilmu-ilmu modern dan filsafat masih terbatas pada pemisahan masalah yang berkaitan dengan sektor private dan tidak menyentuh sektor publik. Keberhasilan mereka baru sebatas pada usaha pemisahan urusan agama dengan urusan negara (masalah pemisahan managemen dalam urusan publik maupun private), agar terjadi transparansi dan selanjutnya terciptalah akuntabilitas dalam kedua bidang tersebut. Antara sektor publik dengan sektor private belum ada jalinan yang erat, atau dikenal dengan gejala sekulerisme sektor publik, sehingga peradaban modern telah melahirkan Perang Dunia, Perang Teluk, dan banyak revolusi yang mengingkari kemanusiaan.

\section{Kritik terhadap Teologi Konvensional Islam}

Sekulerisme tentu bisa menimpa umat Islam. Mungkin tidak separah yang dialami Barat, karena Allah dalam kitab sucinya al-Qur'an memang memerintahkan kita melakukan ritual agama sebagaimana yang dicontohkan oleh Nabi Muhammad SAW. dan kita tidak mungkin menolak eksistensi alQur'an, karena kita mempercayainya sebagai wahyu Allah yang disampaikan kepada Nabi Muhammad, Nabi terakhir. Namun tidak tertutup kemungkinan kalau umat Islam gagal memahami petunjuk Allah dalam al-Qur'an, dengan

vol 4, Online http://io.ppi-jepang.org/article.php?edition=4, pp.66-67 <Diakses 2005/09/03>. ${ }^{8}$ Stephen V. Monsma (1996), Religious Nonprofit Organizations and Public Money: When 
konsekuensi al-Qur'an tidak dapat dijadikan kunci mengatasi krisis yang sedang melanda umat ini.

Gejalanya sudab sangat jelas, semaraknya kehidupan beragama pada tataran ritual atau serimonial dengan berbagai sarana dan prasarana seperti masjid, majelis taklim, madrasah, pesantren dan perayaan hari besar Islam, pelaksanaan puasa Ramadhan, serta Shalat Idul Fitri seakan menunjukkan tingkat perkembangan yang pesat. Kendati dalam situasi krisis multi-dimensional, jumlah jamaah haji Indonesia tercatat masih terbesar meski harus membayar biaya ONH termahal sejagat. Namun realitas sesungguhnya dari kesemarakan beragama tersebut secara kualitatif sama sekali tidak berdampak pada pembentukan akhlak dan moralitas kehidupan sosial. Hal ini tentunya terjadi karena kita belum mempunyai teologi yang menggabungkan urusan private dan urusan publik.

Teologi tradisional tidak mampu menjelaskan gejala modern ini, karena teologi tradisional masih menggunakan pendekatan klasik, seperti yang dikembangkan Filsafat Stoic, ${ }^{9}$ yang mendasarkan diri pada prosedur logika sebagai pisau analisisnya. Pendekatan Sotic ini merupakan pengaruh dari ilmu Aristoteles-Scholastik, bukan pendirian logika asli yang dikembangkan Aristoteles maupun Plato ke dalam dunia Islam. Perhatian utamanya pada definisi, bukannya keterkaitan antar fenomena, sehingga ia kehilangan jejak di dalam usahanya mencari kebenaran. Pendekatan Stoic ini menekankan peranan akal sebagai alat untuk memvalidasi kebenaran ilmu pengetahuan dan memandang pengetahuan berdasarkan prosedur logika saja, sehingga akan menghasilkan standar kebenaran ilmu yang hitam-putih. Karena tidak didukung dengan pendekatan observasi empiris maka tidak mengherankan bila pendekatan ini gagal menangkap realitas kehidupan yang sebenarnya, yang seringkali berwarna abu-abu karena sebagai gabungan standar kebenaran ilmu yang bersifat hitam dan putih sekaligus. ${ }^{10}$

Sebenarnya konsep kebenaran yang menyatu dalam tindakan (Verum et factum convertuntur), sebagai kharakter pengetahuan ketuhanan, telah dikenal pada masa Abad Pertengahan Islam, namun filsafat ini tidak berkembang luas dan kalah populer dengan filsafat Stoic. Pada dunia Islam didominasi oleh epistemologi bayânîyang menekankan pendekatan skriptural terhadap al-Qur'an

Sacred and Secular Mix, Maryland: Rowman \& Littlefield Publishers, Inc., pp. 3-5.

${ }^{9}$ M. Amin Abdullah (2005), "Democracy and Authoritarianism in Isiamic Text: The Implication and the Consequences of having Bayânî type of Islamic Epistemology in the Political Arena”, dalam ICIP Joumal, vol. 2, no. 2, p. 3.

${ }^{10}$ Amos Funkenstein (1986), Theology and the Scientific Imagination: from the Middle Ages to the 
dan Hadits. Pendekatan ini mengalami kesulitan berdialog dengan epistemologi irfân $\hat{\imath}$ (pengetahuan intuitif) maupun burbân $\hat{\imath}$ (pengetahuan filsafat). ${ }^{11}$

Teologi konvensional yang dinumuskan melalui pendekatan skriptural, baik berdasarkan bunyi teks al-Qur'an maupun Hadits, ${ }^{12}$ adalah yang kita kenal dengan rukun iman (aspek keyakinan) yang enam itu. Lalu Rukun Iman ini diimplementasikan dalam bentuk syariah (aspek hukum) yang disebut dengan Rukum Islam yang lima itu. Sebagai suatu paradigma, penjabaran teologi secara konvensional ini boleh saja diperkenalkan, tetapi hal ini jangan sampai menghalangi lahirnya paradigma lain. Kita dapat membangun paradigma baru berdasarkan pendekatan tafsir, pendekatan hermeneutika, maupun membangun suatu teologi baru.

Adalah salah bila teologi dianggap sebagai suatu kebenaran final dan mempercayainya sebagai garansi masuk surga. Rukun iman dan rukun Islam yang menjadi fondasi bangunan teologi Sunni hendaknya juga jangan dianggap final. Bukankah teologi Syi'ah dan juga Mu'tazilah merumuskan rukun iman dan Rukun Islam yang berbeda? Bukankah semuanya bersumber dári al-Qur'an dan Hadits! Kita harus kritis terhadap warisan peradaban dari para pendahulu kita, bukankah kita sudah diingatkan Allah agar jangan mengikutinya secara membabi buta. Kita disuruh mengkritisinya berdasarkan sumber aslinya alQur'an dan Hadits.

Teologi yang sudah ada, baik itu Sunni, Syiah, maupun Mu'tazilah, tidak lepas dari kepentingan politik. Sunni melegitimasi suksesi dari kalangan Quraisy, sementara Syi'ah melegitimasi suksesi dari kalangan keturunan Ali bin Abi Thalib; dan Mu'tazilah menggugat semuanya itu dan mengatakan bahwa semua Muslim yang mampu berhak atas suksesi ini. Kenyataan sejarah menunjukkan bahwa suksesi terjadi dari ketiga pintu itu. Hal ini mengisyaratkan agar kita menghormati paradigma lain, selama mereka didasarkan pada semangat al-Qur'an dan Hadits.

Mantan Rektor al-Azhar, Mahmud Shaltut, dan juga intelektual Prof. Dr. Fazlur Rahman menanggapi perbedaan rukun iman dan rukum Islam dalam Sunni, Syi'ah, dan Mu'tazilah sebagai suatu sunatullâh; dan sebagai Sunni, mereka menantang umatnya agar mengadopsi nilai-nilai universal Islam ke dalam dasardasar Rukun Iman. Mereka juga menyarankan agar mengadopsi prinsip keadilan yang sudah dijadikan prinsip keimanan oleh Syiah dan Mu'tazilah. ${ }^{13}$

Seventeenth Century, Princeton: Princeton University Press, p. 13.

${ }^{11}$ M. Amin Abdullah, op. cit., p. 2.

${ }^{12}$ Lihat QS al-Baqarah (2): 2-4.

${ }^{13}$ Abdurrahman Wahid (2004b), "Konsep-Konsep Keadilan”, dalam bttp://media.isnet.org/ islam/Paramadina/Konteks/Keadilan.html, p. 1 <Accessed 2004/09/22>. 


\section{E. Teologi Baru dalam Sektor Publik}

Teologi baru ini dibangun mengikuti perkembangan mutakhir ilmu-ilmu sosial, yang menggunakan metoda observasi sebagai validasi kebenaran. Pendekatan modern ini akan menyatukan kebenaran dengan perbuatan, mengingat kebenaran itu tidak lepas sama sekali dari realita, sebagai konteks bagi diimplementasikannya kebenaran itu. ${ }^{14}$ Ini merupakan perkembangan modern teologi, yang mencoba menggabungkan teologi dengan filsasat dan iptek, terutama ilmu-ilmu sosial. Dengan begitu, agama digunakan untuk memecahkan persoalan kehidupan modern dan konsekuensinya agama masuk dalam tataran sektor publik. Hal ini tidak dimaksudkan memberlakukan syariah Islam secara legal formal, tetapi syari'ah dalam maknanya yang substansial sebagai nilai-nilai universal, yang diperkenalkan melalui pendekatan kultural. ${ }^{15}$

Teologi baru berpretensi menyusun suatu teori yang didasarkan pada alQur'an dan Hadits. Teologi baru tidak mungkin disusun kalau penafsiran agama kita didasarkan pada pendekatan skriptural, mengingat al-Qur'an dan Hadits sebagai pembimbing umat manusia sampai akhir zaman tidak mungkin menjelaskan suatu permasalahan secara detail. Kita dituntut untuk memahami misi dan pesan yang tersirat di dalamnya. Kalau Islam masih belum dapat menjadi rahmat bagi seluruh alam, maka yang salah bukan al-Qur'annya tetapi kita yang masih gagal menangkap misi dan pesannya.

Teologi baru tidak dimaksudkan untuk menyampaikan suatu kebenaran final, mengingat teologi ini disusun oleh manusia. Sebagai suatu teori, teologi baru ini dimaksudkan sebagai blueprint atau guide line di dalam menapaki kehidupan modern ini. Sudah seharusnya teori atau teologi ini disempurnakan terus, terutama dalam implementasinya di masyarakat.

Teologi didefinisikan sebagai ilmu Ketuhanan, yaitu bagaimana cara mengetahui kebenaran mutlak, atau dengan kata lain, sumber kebenaran. $\mathrm{Di}$ Era modern ini, para ulama juga ditantang untuk memahami perkembangan ilmu-ilmu modern, teristimewa ilmu-ilmu sosial, agar mereka dapat menemukan kebenaran di era modern ini. Teologi tidak hanya menyangkut pengetahuan tentang Tuhan dengan sifat-sifat dan eksistensi-Nya, tetapi juga terkait erat dengan masalah kemanusiaan di dunia ini. Oleh karena itu, kaum Sunni tidak cukup hanya menjalankan kewajiban agama sebagaimana yang dijabarkan dalam

14 Sumartana (2005), "Kepekaan Teologi pada Tanda Zaman", dalam bttp:// wrew.tokobindonesia.co.id/ensiklopedi/s/sumartana-th/sumartana_tb2.sbtml, p. 7 <Diakses 2005/ $03 / 22>$.

${ }^{15}$ Amos Funkenstein, op. cit., p. 13. 
Rukun Iman dan Rukun Islam konvensional; kita juga harus menaruh perhatian pada masalah-masalah kehidupan seperti korupsi, keadilan, kemiskinan dan kelaparan dalam masyarakat. ${ }^{16}$

Saya sependapat dengan Cak Nur yang memaknai iman dan akidah sebagai suatu hal yang berbeda. Iman menuntut sikap rendah hati, selalu terbuka bagi semua informasi kebenaran, tetapi sekaligus juga dinamis untuk mengejar kebenaran itu dari sumbernya, yaitu Sang Kebenaran itu sendiri yang oleh alQur'an Dia Yang Maha Benar itu disebut Allah. Adapun akidah sebagai sebuah paham atau madzhab kalam merupakan produk sejarah yang oleh sebagian umat Islam akidah itu dianggap telah selesai dan oleh karenanya menjadi tertutup. Implikasi dari pemahaman semacam ini tentu akan merelativisir doktrin atau madzhab dalam Islam yang telah mapan, baik dalam bidang fiqh, kalam, filsafat maupun sosial-politik. ${ }^{17}$

Memang kita perlu menyusun pemikiran agama dari berbagai paradigma agar bisa didapatkan pemahaman yang utuh terhadap Islam, yang sesuai dengan konteks bagi diimplentasikannya ajaran-ajaran Islam dalam kehidupan di dunia ini. Barangkali yang cukup menarik untuk diperhatikan dan dikritisi adalah secara harfiah istilah-istilah "Dâr al-Islâm" dan "Dâr al-Hiarb" tidak terdapat dalam alQur'an. Sebagaimana telah diisyaratkan, istilah-istilah itu banyak terdapat dalam kitab-kitab fiqh; seperti halnya dengan istilah "fiqih" ( $f(q b)$ itu sendiri, bersama dengan istilah-istilah syariah (syari'ab), kalam, tasauf (tashawewnf), hikmah (falsafab) dan lain-lain - yang walaupun terdapat dalam al-Qur'an namun mempunyai makna semantik yang berbeda - istilah-istilah "Dâr al-Islâm" dan "Dâr al- $\underline{H}$ arb" juga tumbuh sebagai bagian dari pemikiran Islam yang tertuang dalam ilmu figh. ${ }^{18}$

Kita juga perlu kritis terhadap pemahaman QS 3: 19 "Inna ad-dîna indallâbi al- islâm" (Sesungguhnya Agama disisi Allah hanyalah Islam). Kita harus memahami ayat ini dalam kaitannya dengan ayat-ayat al-Qur'an yang lain maupun dengan bantuan penjelasan tafsir terhadap ayat-ayat al-Qur'an. Cobalah kita perhatikan lebih mendalam deretan tiga ayat suci berikutnya Q.S. Ali Imran (3): 83-85. Dari firman-firman itu dengan jelas kita dapatkan bahwa perkataan

${ }^{16}$ A. Hasyim Muzadi (2005), "Busung Lapar dan Konstruksi Keimanan" dalam Republika 19 June 2005 http://groups.yahoo.com/group/kedungcinta/message/2165, p. 3 <Diakses 2005/07/ $12>$.

${ }^{17}$ Komaruddin Hidayat (1995), "Kata Pengantar" dalam Nurcholish Madjid Islam Agama Peradaban: Membangun Makna dan Relevansi Doktrin Islam dalam Sejarah, Jakarta: Paramadina, Pp. viii-ix.

${ }^{18}$ Nurcholish Madjid op. cit., pp. 259-260. 
dan pengertian Islam, pertama, dikaitkan dengan pola wujud seluruh alam raya, khususnya makhluk-makhluk yang menjadi penghuninya, yaitu hawa semua yang ada ini tunduk-patuh dan pasrah kepada Tuhan Maha Pencipta, baik secara sukarela maupun terpaksa; kedua, dikaitkan dengan semua agama yang diturunkan kepada para Nabi dan Rasul sebelum Nabi Muhammad, dan beliau ini serta para pengikut beliau diperintahkan untuk menyatakan percaya atau beriman kepada semua itu tanpa membeda-bedakan satu dari yang lain, dan semua para Nabi serta pengikut mereka itu adalah sama-sama menempuh sikap hidup pasrah kepada Tuhan, yakni muslimîn; dan ketiga, sebagai kesimpulan dan penegasan berdasarkan itu semua maka barangsiapa menganut selain Islam sebagai pola keagamaannya, ia tidak akan diterima. ${ }^{19}$

Pemahaman pengertian Islam seperti tersebut di atas memungkinkan kita merumuskan suatu teologi Islam yang tidak punya interest politik sama sekali, bahkan terhadap kelompok Islam sendiri. Kebenaran Islam berlaku universal bagi semua makhluk baik yang percaya pada Islam maupun tidak, bukankah Tuhan bersifat Maha Penyayang (ar-Rabmân) terhadap semua makhluknya. Kita juga harus mengikuti jejak Allah dalam menyampaikan kebenaran, yaitu kepada semua makhluk. Dengan demikian dakwah Islam hendaknya disampaikan kepada semua makhluk sebagai wujud dari Rabmatan lil 'alamîn (rahmat bagi seluruh alam). Memang kebenaran tidak hanya disampaikan secara doktriner atau normatif saja, tetapi kebenaran itu memiliki ciri-ciri dan karakteristik yang bisa diamati secara empiris. Keadilan, sebagai salah satu bentuk dari kebenaran, harus berlaku obyektif kepada semua makhluk, tidak hanya bagi Islam saja.

Teologi baru memungkinkan umat Islam bekerjasama dengan umat agama lain secara tulus dalam menegakkan perintah Allah di wilayah publik sektor. $\mathrm{Hal}$ ini untuk mencegah berkembangnya sekulerisme di wilayah publik sebagaimana yang telah menimpa Barat, dengan dampak yang sangat menginjakinjak kemanusiaan secara global. Karena itu, Muslim dan non-Muslim perlu bekerjasama mengembangkan etika global yang didasarkan pada pemahaman yang mendalam tentang agamanya. Perang bersama terhadap sekulerisme adalah sesuai dengan ajaran paling inti dalam Islam, Monotheisme (taubîtd) bahwa segala sesuatu dimulai dan berakhir pada Allah. Hossein Nasr menjabarkan konsep tauhid secara meyakinkan bahwa "Unity is the nature of the Absolute, a method of integration, a means of becoming whole and also a means of realizing the profound oneness of all existence". ${ }^{20}$

${ }^{19}$ Ibid, pp. 261-262.

${ }^{20}$ Seyyed Hossein Nasr (1985), Ideals and Realities of Islam, London: Allen and Unwin. 
Dari diagram di bawah ini, kita dapat membedakan antara Islam sebagai syariah dengan fiqh, yang merupakan bentuk legal-formal syariat Islam. Bagi kalangan Sunni, teologi disini disamakan dengan rukun iman; sedangkan figh merupakan penjabaran dari kewajiban-kewajiban agama sebagaimana disebutkan dalam Rukun Islam. Fiqh ini harus mendapat legitimasi dari teologi, sebagai sumber dari ilmu Ketuhanan dan sekaligus sebagai sumber dari kebenaran. Dalam sejarah Islam, figh telah memerankan diri dalam sektor publik. Karena peran itu begitu menonjol maka timbul kesan kalau Islam sebagai agama yang kurang memberi kebebasan kepada individu. Dalam kenyataannya, rukun iman lebih mencerminkan kebebasan individu, sehingga kita bisa mengatakan sebagai sektor private karena manusia harus mempertanggungjawabkan secara langsung kepada Allah. Agar tidak ada kesan Islam mengutamakan masyarakat maka figh yang selama ini diperankan dalam sektor publik perlu dikurangi dominasinya agar tidak melanggar makna rukun iman yang bersifat private. Sudah sepatutnya bila sektor publik merupakan hasil sinthesa dari rukun iman (sektor private) dan rukun Islam (sektor umat) dan menghasilkan apa yang dinamai Rukun Publik. ${ }^{21}$

Diagram Paradigma bagi pengembangan teologi baru di sektor publik

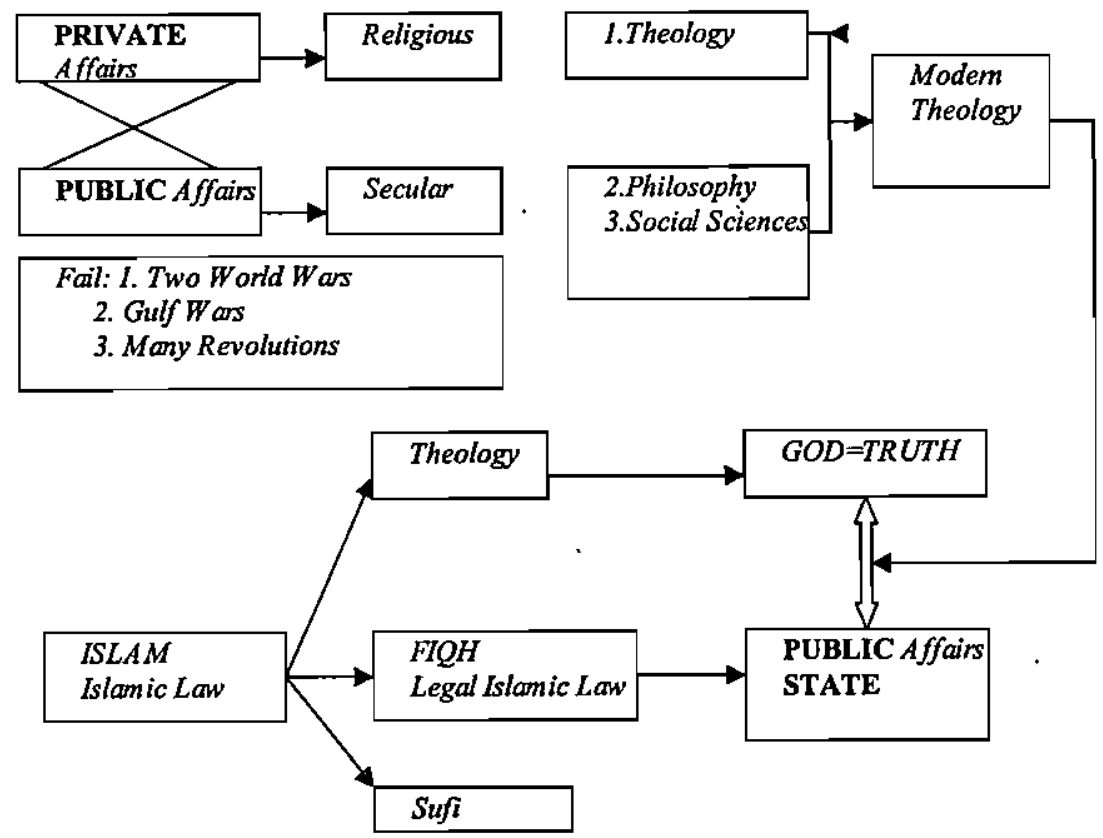

${ }^{21}$ Abdurrahman Wahid (1999), Prisma Pemikiran Gus Dur, Yogyakarta: LKiS. 


\section{DAFTAR PUSTAKA}

A. Hasyim Muzadi (2005), "Busung Lapar dan Konstruksi Keimanan" dalam Republika 19 June 2005 bttp://groups.yaboo.com/group/kedungcinta/message/2165, p. $3<$ Diakses $2005 / 07 / 12>$.

Abdurrahman Wahid (1999), Prisma Pemikiran Gus Dur, Yogyakarta: LKiS. Abdurrahman Wahid (2004), "Konsep-Konsep Keadilan" dalam bttp:// media.isnet.ong/islam/Paramadina/Konteks/Keadilan.btml.p. $1<$ Accessed 2004/ $09 / 22>$.

BBC News (2004) "UK among most secular nations", dalam bttp://news.bbc.co.uk/ 1/hi/programmes/wtwtgod/3518375.stm, pp.1-3<Diakses 2005/06/20>.

Funkenstein, Amos (1986), Theology and the Scientific Imagination:from the Middle Ages to the Seventeenth Century, Princeton: Princeton University Press.

Komaruddin Hidayat (1995), "Kata Pengantar", dalam Nurcholish Madjid Islam Agama Peradaban:Membangun Maknadan Relevansi Doktrin Islam dalam Sejarah, Jakarta: Paramadina, pp. viii-ix.

M. Amin Abdullah (2005), "Democracy and Authoritarianism in Islamic Text: The Implication and the Consequences of having Bayani type of Islamic Epistemology in the Political Arena" dalam ICIP Journal, vol. 2, no. 2. Nurcholis Madjid (1998), "Dialog Agama-agama dalam Perspektif Universalisme al-Islam" dalam Komaruddin Hidayat dan Ahmad Gaus AF eds. Passing Over: Melintas Batas Agama, Jakarta: Gramedia.

Nurcholish Madjid (1995), Agama Peradaban:MembangunMakna dan RelevansiDoktrin Islam dalam Sejarah, Jakarta: Paramadina, pp. 259-260.

Nurcholish Madjid (1995), Islam Agama Peradaban: Membangun Makna dan Relevansi Doktrin Islam dalam Sejarah, Jakarta: Paramadina.

Monsma, Stephen V. (1996), Religious Nonprofit Organizations and Public Money: When Sacred and Secular Mix, Maryland: Rowman \& Littlefield Publishers, Inc. Saefur Rochmat (2005), "Kebangkitan Agama di Era Modern?" dalam Inovasi, Tahun 7, vol 4, Online http://io.ppi-jepang.org/article.php?edition =4, pp.66-67 $<$ Diakses 2005/09/03>.

Seyyed Hossein Nasr (1985), Ideals and Realities of Islam, London: Allen and Unwin. Sumartana (2005), "Kepekaan Teologi pada Tanda Zaman", dalam http:// wrew.tokobindonesia.co.id/ensiklopedi/s/sumartana-th/sumartana_th2.shtml, p. 7 $<$ Diakses 2005/03/22>. 